\title{
Digital India under ICT Regime: A Case Study
}

\author{
Swaleha Zubair, PhD \\ Assistant Professor \\ Department of Computer Science, \\ Aligarh Muslim University, Aligarh
}

\author{
Ravi Kumar Gaur \\ Department of Computer Science, \\ Aligarh Muslim University, Aligarh
}

\begin{abstract}
Digital India, a campaign of government of India, has been launched to ensure electronic access of various government services to its citizens. Among various possible strategies, introduction of improved online infrastructure along with faster internet connectivity are likely to make great impact in making an action digitally empowered .The present report is an effort to check if a representative city Aligarh of Uttar Pradesh, India is ready for making such digital living transition in spite of its old living style.
\end{abstract}

\section{Keywords}

Digital India, Digital Technology, e-Kranti, e- Governance, Digital India Acceptance, cashless

\section{INTRODUCTION}

The journey towards a digitally advanced India began in the early 90s that involves introduction of a range of $e-$ governance programs. However, its impact was limited. India's fast growth rates since 1991 have been the product of a privileged few. The benefits reaped off too have primarily gone to elite class. The denouement of Digital India will be no different. However, the opacity of technocratic development prevents it from realizing this reality. The

Indian middle class considers themselves as really "middle", having expanded greatly by pulling up vast numbers from the poor classes in the last 25 years. However, a revealing statistic which will prick this delusion, as the Pew Research Center points out that in the period from 2001 to 2011, while

poverty was reduced both in China and India, the middle class grew from 3 per cent to 18 per cent in China, while it expanded from 1 per cent to 3 per cent in India. Though the measurement of the middle class numbers is contentious, even other assessments, like that of the Center for Global Development, put the number at 5.88 per cent. The hollowness of the fancy terms Digital India, Start-up India and Make in India cannot sound louder for those who will access the Internet, start business ventures and produce goods, but do not have basic facilities as human beings. India ranked 55 out of 76 countries in the Global Hunger Index last year, behind Nepal. Half of rural India lives in mud houses and works as casual manual labor. And these lives are supposedly going to be transformed by the magic wand of broadband access (which stands at 1.2 per cent of the population now).
It is time to realize that the future of India is not in the "fundamental debate" about the "choice between Android, iOS or Windows". It lies in the building of a radically democratic society, which will not sacrifice human beings for technological utopias and which will ensure that the benefits of technology are harnessed in the most socially and ecologically manner.

The Government of India is futurists and think tankers have a visualization to foresee impact of digitally empowered Information and Communication Technology (ICT) in uplifting of the country. In spite of vastness of the country in terms of its geographical area as well as dense population, the program has great deal of promise and associated benefits. The campaign to improve Information and Communication Technology (ICT) in schools was launched in December, 2004 and was revised in 2010 to provide opportunities to secondary stage

Students to build upon their ICT skills by making use of available computer aided learning process. The Scheme was a major breakthrough to bridge the digital divide amongst students with various socio-economic and other geographical backgrounds.

\section{SCOPE OF DIGITAL INDIA \\ 2.1 DigitalUmbrellato Every Citizen}

- Availability of high speed internet for service delivery to citizens

- $\quad$ Providing bank account to each citizen

- Shareable private platform and space on a public cloud

- Safety and security in cipher world

\subsection{Governance and Services on thought internet}

- Service availability to all in real time though online channels.

- Portable citizen entitlements and their availability on the cloud

- Provision for doing business affairs in easy way.

- Making cashless transactions.

\subsection{Technologicalawareness update}

- Knowledge of internet and use of computer for all. 
- Access and availability of resources to common people.

- No need of providing documental proof of physical domicile or income etc.

\section{IMPORTANCE OF DIGITAL INDIA}

Digital India program mainly involves various departments of Government of India. It inculcates a huge number of thoughts and ideas into a single, clear vision leading to timely achievements of the goals. Digital India is implemented entirely by Government agencies with coordination of Department of Electronics and Information Technology (DeitY). Digital India mainly aims at providing thrust to nine pillars of growth, namely, Broadband Highways, Universal Access to Mobile Connectivity, Public Internet Access Program, e-Governance: Reforming Government through Technology, e-Kranti - Electronic Delivery of Services, Information for All, Electronics Manufacturing, IT for Jobs and Early Harvest Program. Each of these areas is a complex program in itself and cuts across multiple Ministries and Departments.

\section{WHY DIGITAL INDIA NOT BECOMING REALITY?}

There are multiple challenges in successful implementation due unawareness of people, lack of technologically aware citizens. And some of them are:

\subsection{Digital divide}

This is a serious problem and has to be given heed because if people do not know how to reap the benefit of digital world then how the dream of coming digital becomes a reality. According to a survey $26 \%$ people are still illiterate this very big number has a measure issue.

\subsection{Bad connectivity}

According to some estimate in India more than 80 lakhs hotspots are required but only 31000 hotspots are available to reach to global 150 people per Wi-Fi hotspot.

\subsection{Cash dependency}

India is still totally dependent on cash based economy while most of the countries are switching towards cash less system.

According to some reputed agencies India is still very far in becoming digitally independent as the cash less transactions of India has been estimated at only 2 per cent of the total transactions made while countries like Singapore, France, and Sweden are around 60 per cent.

\subsection{Cyber Security}

In digital world security has been a big issue from the beginning and this has been growing day by day. On the one side India is trying to becoming Digital, some hackers are reminding how secure our current systems are.

It was believed that the card and PIN details might have been leaked due to which customers were advised to change the PINs of their ATM-cum-debit cards.

\subsection{Internet cost}

The internet cost in India is still substantially high. There is no $\mathrm{Wi}-\mathrm{Fi}$ at public places and if people do not get their monthly data packs recharged; there is no way they can be connected to make online payments.

\subsection{Charges on cards, online transactions}

These are additional charges that are levied by the vendors when they offer an online payment facility.

\subsection{Non-tech-savvy}

1.1 Not many people are comfortable using computers or mobile phones and depend on their children when it comes to using the gizmos.

\subsection{Smart phone afford ability}

Several companies have come up with new and inexpensive phones but still not affordable for most of the population in the country.

\subsection{Infrastructure/phone battery}

India still lacks when it comes to supporting a mobile society. It is extremely difficult to find a public charging point if the phone battery discharges. Even metro stations or railway stations in the tier one cities do not provide that infrastructure.

\subsection{Not enough bank accounts}

Most people still do not have bank accounts. Most often there is just one account per family which also limits the number of cards people can have individually.

\subsection{Banks not ready}

A cashless society needs a proper infrastructure. The banks need to be fully equipped to handle the surge ine transactions. Infrastructure is also needed in terms of opening more accounts in the banks.

\subsection{Acceptance}

It can be argued that more research work is required to find the actual worth of such developed projects. Although most part of India has been benefited by the developed technologies, yet it is difficult to scale up these initiatives to provide benefit to all Indians, and fundamental attitudinal and institutional change is still a problem. ICT research has 


\section{Bank accounts}

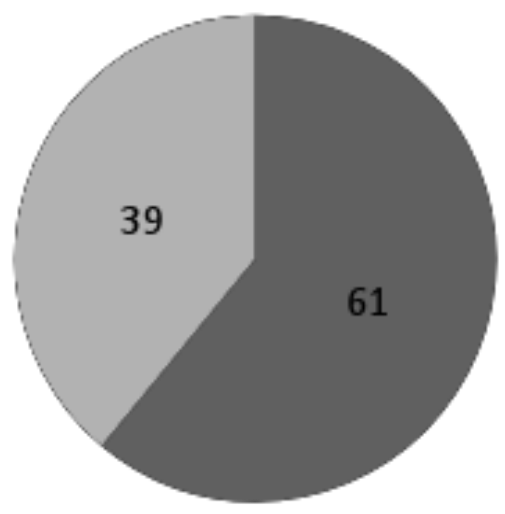

Bank account holders

Non-bank account holders

\section{Figure 1}

been conducted in Kerala, Andhra Pradesh, and Gujarat, but poorer states such as Bihar and Orissa are rarely mentioned. The program has been chosen by multiple countries including the US, Japan, South Korea, the UK, Canada, Australia, Malaysia, Singapore, Uzbekistan and Vietnam.

\section{DATA COLLECTION}

In order to analyze the impact of digital India campaign in Aligarh district in the present scenario, we have conducted a survey by taking a sample data of 1000 individuals.

The survey questionnaire has been drafted taking 5 main questions into consideration which are:

1. Availability of bank accounts

2. Nature of digital transactions preferred

3. Channels of digital connectivity
4. Ease of Access and use of digital technology

The data in figure 1 represents the percentage of account holders in the sample of the present study. The digital India cannot be considered successful until and unless majority of the population do have their respective bank accounts which enables transparency and ease of cash management in the country. Here, majority of the respondents have one or more bank accounts showing a positive sign towards digital India.

For a country aspiring to be digital, there is a crucial need for the sources which minimizes the dependency on cash and are based on cash less transactions. Fortunately, there is an abundance of sources like ATMs (Automated Teller Machines), Internet banking, mobile banking, E-wallets and likewise which do not only decrease our dependency on cash but also ease us out in making transactions from the comfort of our home.

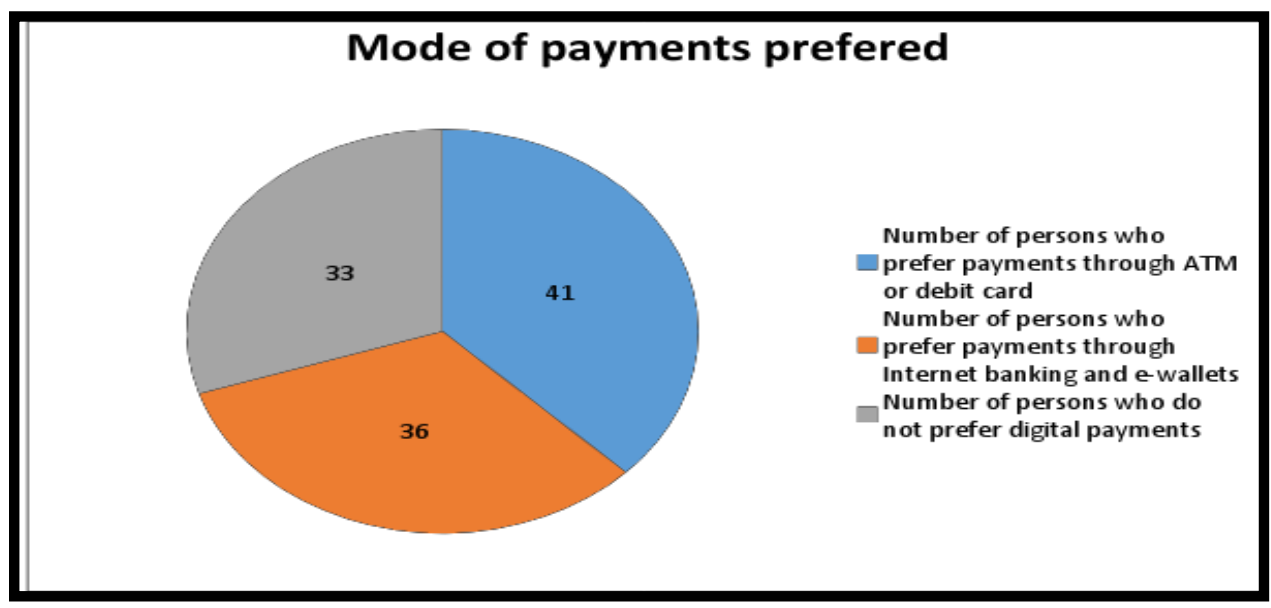

Figure 2 
The pie-chart figure 2 shows the modes of digital payments preferred by the respondents. Majority of the respondents prefer the use of plastic cards (ATMs or debit card) instead of using internet banking. The data suggest that most of the respondents taken in the sample study lack the needed basic technological skills or else they consider it to be in secured to conduct a transaction digitally. They find it more secure to visit an ATM like they used to visit banks and get the cash in hand.

While most of the respondents prefer digital cards, there are a vast number of persons who prefer to conduct transactions through internet banking and e-wallets as they find it more convenient and safe.

More and more companies are entering into the segments of ewallets with a large variety of offers and discounts.

Some of the respondents did not show interest in digital payments and transactions. In spite of the fact that they have ATMs or debit cards from their respective banks they wish to prefer payments through cash only.

The concept of digital technology is impossible to imagine (see figure 3) without the availability of state of the art technologies used in the area of internet traffic. That is why the researcher tried to find them ousted channel for internet connectivity.

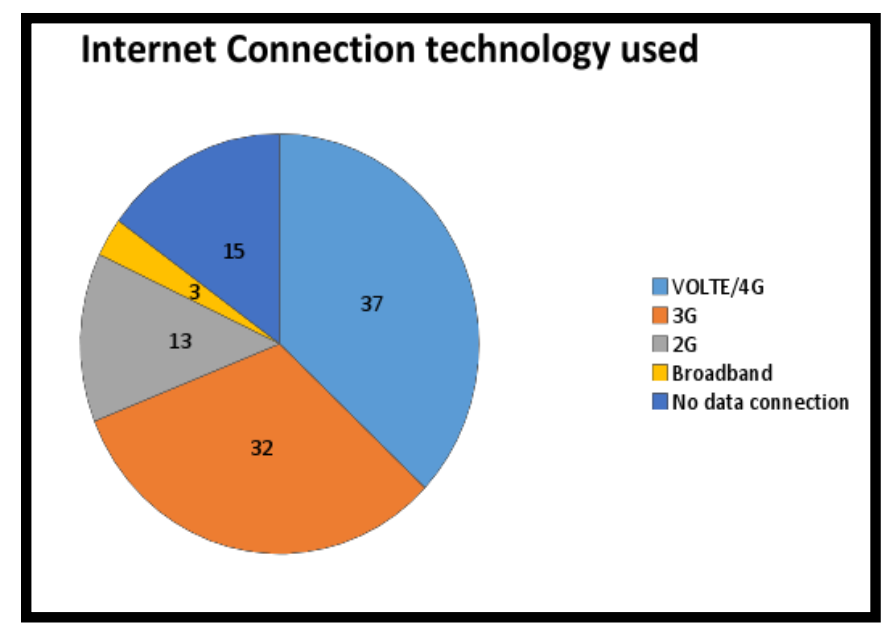

Figure 3

The VOLTE (Voice over Long Term Evolution) and 4G technologies have been found to be used by 37 per cent of the population. While $3 \mathrm{G}$ comes on the second place with 32 per cent respondents. The use of broadband connectivity has been recorded to be only 3 per cent whereas 13 per cent of the respondents are still using $2 \mathrm{G}$ services.

Around 70 per cent of the respondents are either on $3 \mathrm{G}, 4 \mathrm{G}$ or VOLTE which is all considered to be good channels of internet connectivity but on the other side of the coin 15 per cent of the respondents still do not have any internet connectivity with them. The data is suggesting that while it is a crucial need of fast internet connectivity options for most of the respondents while a considerable number of respondents are happily living without any internet in their domains.

The chart in figure 4 shows the sense of security and the level of acceptance regarding the digital technology as a whole. The chart is a simple representation showing 31 percent of respondents as insecure of internet technology and digital banking, while the remaining find it as a boon and have embraced it into their livelihoods.

The introduction of digital technology is neither too fresh nor too old in India but to most of the rural masses it is still new and that is why most of the people still doubts about its security. The lack of proper knowledge about technology does not allow them to accept it in their daily use.

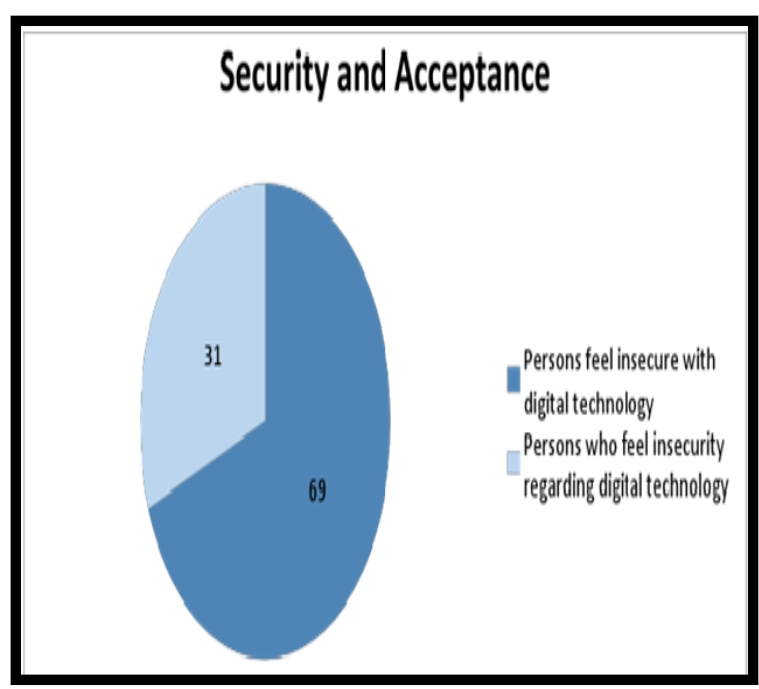

Figure 4

\section{STEP TOWARDS CASH LESS INDIA}

Digitally delivering services will offer good connectivity to the system that facilitate user to get benefits of various government plans and policies as soon as they are launched. It will also promote online business by making the financial transaction easy by electrification and indiscriminate transaction. The major idea is to connect the rural area with urban technology, also to provide e-services to remote villages that are forced to do pity works which involve a lot of paper work. In cashless India, the transaction can be done in cost effective manner and can be accessed by a simple phone call.

There is no doubt that by introducing Aadhaar, an exclusive identity mode, government has tried to introduce transparent and digital economy. The government has paved the way to make the country a pure, transparent and cash less economy.

\section{CONCLUSIONS}

The data analysis suggests that Aligarh city of India has a huge potential to grasp and absorb digital technology with the help of its continuous growth and demand of internet traffic. In a manner similar to representative city Aligarh, a digitally connected India can help in improving social and economic condition of people living in rural areas through development of nonagricultural economic activities apart from providing access to education, health and financial services. However, it is important to note that ICT alone cannot directly lead to overall development of the nation. The overall growth and development can be realized through supporting and enhancing elements such as literacy, basic infrastructure, overall business environment, regulatory environment, etc. Further, Security should be the most important aspect at all level of operation for the digitally empowered knowledge economy of the country. There is no looking back for Digital India and 
hence there is no doubt in success of Digital India movement

\section{FUTURE SCOPE AND SUGGESTIONS}

Digital India is an initiative taken by the Prime Minister of India to make the country a digitally blooming nation.

He has a vision to help each individual grow digitally. His dreams would come true only when following strategies would be implemented

1. Broadband Highways.

2. Digital Empowerment of Citizens

3. Universal Access to Phones.

4. Public Internet Access Program.

5. E-Governance- Reforming government through Technology.

6. eKranti-Electronic delivery of services.

7. Access to information to all

8. Electronics Manufacturing-Target NET ZERO Imports.

9. Quality education reaches most in accessible areas and is driven by digital learning

10. Cyber security becomes an integral part of national security.

11. Connectivity issues must be resolved before dreaming about a cashless society.

\section{REFERENCES}

[1] http://mhrd.gov.in/ict_overview

[2] http://www.digitalindia.gov.in/content/vision-and-vision-areas

[3] http://www.news18.com/news/tech/digital-india-5-majorproblems-that-government-needs-to-Address-quick1334984.html

[4] Thomas, PradipNinan (2012-07-11).DigitalIndia: UnderstandingInformation, Communicationand Social Change. SAGE Publications India.

[5] "Vietnam may emulate Digital India, seekscooperation onegovernance", Hindustan Times, 28 March2017

[6] http://indianexpress.com/article/explained/digital-paymentscyber-security-data-theft-hacking- demonetisation-4422513/

[7] http://www.businesstoday.in/current/economy- politics/hereare-the-top-cashless-countries-in-the-world/story/241430.html

[8] http://indianexpress.com/article/technology/tech- newstechnology/projects-and-policies-launched- at-digital-indiaweek/

[9] http://www.thehindu.com/todays-paper/tp-business/Cabinetnod-for-rural-digital-literacy-programme/article17265514.ece

[10] http://www.thehansindia.com/posts/index/Khammam$\mathrm{Tab} / 2017-05-02 /$ Digital-literacy-classes-forunemployed/297175

[11] https://www.hindustantimes.com/india-news/vietnam-mayemulate-digital-india-seeks-cooperation-on-egovernance/story- GTgaVp5IFYKVNInNeaj6BN.html

[12] https://www.gadgetsnow.com/tech-news/Mark-Zuckerbergchanges-his-profile-picture-to-support-Digital-

India/articleshow/49128369.cms
[13] https://www.moneycontrol.com/news/ business/companies/digital-india-to-propeleconomy-to-its-best-era-oracle--1326855.html

[14] http://epaper.thestatesman.com/c/6714327

[15] http://www.financialexpress.com/economy/indiainternet-conference-2017-minds-meet-on-countrysdigital-future/616904/

[16] http://www.financialexpress.com/indianews/cabinet-approves-pradhan-mantri-gramindigital-saksharta-abhiyan/543139/

[17] http://vikaspedia.in/e-governance/digitalindia/national-digital-literacy-mission

[18] https://www.livehindustan.com/news/national/articl e1-modi-cabinet-approves-pradhan-mantri-gramindigital-saksharta-abhiyan-697220.html

[19] http://www.newindianexpress.com/cities/bengaluru /2016/mar/15/Government-School-in-RemoteBandahalli-Village-Gets-Inspired-by-Digital-India911767.html

[20] http://www.livemint.com/Politics/dzh7h nHafnvVI8hoIlNqPI/GST-to-take-care-of-manyof- ecommerce-firms-tax-issues-IT.html

[21] https://books.google.co.uk/books?hl=en\&lr=\&id=S OqICwAAQBAJ\&oi=fnd\&pg=PT $8 \& d q=$ digital + in dia\&ots=nkr0YimG4q\&sig=NMK1jLDfwRGLZH fzTtUTyPjugQc\#v=onepage\&q $\& \mathrm{f}=$ false

[22] http://www.indiagovernance.gov.in/files/ICT-forbroader-dev-in-India.pdf

[23] http://indianexpress.com/article/cities/chandigarh/d igital-india-campaign-panchkula-comes-out-ontop-among-all-districts-of-haryana/

[24] https://www.deccanchronicle.com/technology/inother-news/181016/data-xgen-technologieslaunches-email-address-in-local-indianlanguages.html

[25] http://trak.in/tags/business/2016/08/01/localregional-language-email-address-vernacular-push/

[26] http://indianexpress.com/article/cities/chandigarh/d igital-india-digital-india-initiative-softwaretechnology-park-of-india-software-technologypark-in-panchkula-panchkula-news-under-thedigital-india-initiative-software-technology-parkof-india/

[27] https://web.archive.org/web/20150515073907/http: //india.gov.in/spotlight/digilocker-onlinedocument-storage-facility

[28] http://articles.economictimes.indiatimes.com/201410-07/news/54735540_1_biometric-attendancesystem-government-employees-attendance-records.

[29] https://economictimes.indiatimes.com/news/econo my/finance/government-unveils-umang-app-forcitizen-services/articleshow/61769676.cms

[30] http://www.businessstandard.com/article/politics/modi-s-new-mobilefriendly-website-launched-116011500919_1.html

[31] http://previewtech.net/digital-india- botnet/ 